\title{
Urban gardens: Part of a whole system approach
} Response \#2 to Hallsworth and Wong's viewpoint, "Urban gardening: A valuable activity, but..."

Laura Lavid

Florida Organic Growers

Hallsworth and Wong ask the question, "Does encouraging urban gardening in private and/or community lots meaningfully improve [Vancouver's] food system?" (2013, p. 3). They believe the answer is no, but community gardens and urban agriculture do impact a city's food system. Are they the only solution? No. In our world of recessions and fiscal cliffs, so much seems to revolve solely on economics while other significant benefits are often discredited or diminished. Community gardens are important aspects of an urban landscape for its people and environment, but also do impact the economics, on the individual and community levels as well.

Even though most plots are relatively small, a community gardener is able to produce a significant amount of produce. During World War II, "20 million victory gardeners produced 44 percent of the fresh vegetables in the United States" (WhyHunger, 2011, "Vegetables for Victory," para. 2). More recently, "studies have estimated that a

Laura Lavid is Community Food Project Coordinator at Florida Organic Growers, P.O. Box 12311, Gainesville, Florida 32604 USA; +1-352-377-6345; laura@,foginfo.org community garden can yield around USD500 to USD2,000 worth of produce per family a year" (PolicyLink, n.d., "Why Use It?" bullet "Save families money...”). And not only do community gardeners grow healthy produce, but they eat it. A study in Denver found that compared to nongardeners or home gardeners, community gardeners ate significantly more fruits and vegetables (Litt, Soobader, Turbin, Hale, Buchenau, \& Marshall, 2011). While the food grown in community gardens is not enough to sustain one, it does affect the gardener's food budget and is healthy produce that otherwise may not have been accessible to him or her. "A study of all food stores in three lowincome zip codes in Detroit found that only 19 percent, or fewer than one in five stores, carried a minimal 'healthy food basket' [of] products based on the food pyramid" (Pothukuchi, 2003, p. 5). Additionally, for many immigrants, this might be the only way to have access to crops they have a tradition of eating.

Community gardens also affect the economic health of a neighborhood. They are part of making a neighborhood a desirable place to live, including reducing crime and increasing neighborhood 
attachment. Additionally, they do affect the prosperity of a neighborhood. "A New York University study examined over 636 New York City community gardens and found a statistically significant, positive effect on sales prices of residential properties within a 1,000 foot radius of a community garden when compared to properties outside the 1,000 foot ring, but still within the same neighborhood" (Been \& Voicu, 2006).

Additionally, some community garden and urban agricultural projects work with disadvantaged populations to teach farming and business skills. These programs provide job training to groups such as youth, refugees, and individuals who are homeless. The intention of these programs is training, but in the process they also provide a valuable product: fresh, healthy, affordable produce. One such program, New Roots for Refugees, generated more than USD120,000 in revenue, including USD30,000 worth of produce to food stamp recipients in 2012.

As Hallsworth and Wong point out, the city of Vancouver acknowledges that there are multiple benefits of urban gardening, not just economic or food security: "In 2006, the Vancouver city government enacted bylaws to promote community gardens and other forms of urban agriculture, as important neighborhood gathering places to promote 'sustainability, neighborhood livability, urban greening, community building, social interaction and food production."' Community gardens increase food security with improved access to healthy, local food, address social justice, improve individual and community health, encourage resilient communities, offer therapeutic benefits, beautify neighborhoods, and much more. Community gardens and urban agriculture are just one piece of a new food system that values all aspects of the system to promote a more just and sustainable society where not only healthy food is accessible and affordable but also where local communities thrive.

\section{References}

Been, V., \& Voicu, I. (2006). The effect of community gardens on neighboring property values (New York University Law and Economics Working Papers No. 46). Available from http://1sr.nellco.org/nyu lewp/46

Hallsworth, A., \& Wong, A. (2013). Urban gardening: A valuable activity, but... Journal of Agriculture, Food Systems, and Community Development, 3(2), 11-14. http://dx.doi.org/10.5304/jafscd.2013.032.010

Litt, J. S., Soobader, M., Turbin, M. S., Hale, J., Buchenau, M., \& Marshall, J. A. (2011). The influences of social involvement, neighborhood aesthetics and community garden participation on fruit and vegetable consumption. The American Journal of Public Health, 101, 1466-1473.

New Roots for Refugees. (2013). 2012 program report. Retrieved from http://www.newrootsforrefugees.org/

PolicyLink. (n.d.). Urban agriculture and community gardens: Why use it? Retrieved January 2013 from http://www.policylink.org/site/c.lkIXLbMNJrE/ b.7634055/k.102B/Urban Agriculture and Community_Gardens.htm

Pothukuchi, K. (2003). The Detroit food system: A handbook for community planners. Wayne State University. In: Community Food Security Coalition. (October 2003). Urban Agriculture and Community Food Security in the United States: Farming from the City Center to the Urban Fringe. Retrieved from http://www.foodsecurity.org

WhyHunger. (2011). Introduction: Community gardens. Retrieved from http://www.whyhunger.org/ getinfo/showArticle/articleId/74 